\title{
RAPD-PCR Fingerprinting and Southern Analysis of Xanthomonas axonopodis pv. dieffenbachiae Strains Isolated from Different Aroid Hosts and Locations
}

\author{
M. H. R. Khoodoo and Y. Jaufeerally-Fakim, Biotechnology Unit, Faculty of Agriculture, University of Mauritius, \\ Réduit, Mauritius
}

\begin{abstract}
Khoodoo, M. H. R., and Jaufeerally-Fakim, Y. 2004. RAPD-PCR fingerprinting and Southern analysis of Xanthomonas axonopodis pv. dieffenbachiae strains isolated from different aroid hosts and locations. Plant Dis. 88:980-988.

Anthurium blight, caused by Xanthomonas axonopodis pv. dieffenbachiae, is a systemic disease of Anthurium and other aroids. The aims of this work were to study the genetic diversity among $X$. axonopodis pv. dieffenbachiae strains and to identify, from the polymerase chain reaction (PCR) profiles, DNA probes that would be specific for the pathovar dieffenbachiae. Twenty-five $X$. axonopodis pv. dieffenbachiae strains, isolated from different hosts and geographical locations including Mauritius, were fingerprinted using the random amplified polymorphic DNA (RAPD)-PCR technique. The fingerprints were analyzed by the National Taxonomy System Software (NTSYS). The specificity of some of the RAPD fragments selected from PCR profiles was tested by Southern analyses of the PCR products. Ten arbitrary primers were chosen from an initial set of 111 decamers. Two hundred and nine RAPD markers were generated in eight individual DNA profiles. A correlation was found between the serotypes and the RAPD profiles for some groups of isolates. A possible link was also observed between the host range of the isolates tested and their RAPD profiles for strains isolated from Dieffenbachia and Philodendron. These results were confirmed by Southern analysis. Cluster analysis by the unweighted pair group method, arithmetic average (UPGMA) confirmed that the pathovar is genetically diverse with some strains that were clustered together showing similar host preferences. DNA probes with a potential use in molecular diagnostics of Anthurium blight were identified. This preliminary work could be used to develop PCR primers that will enable the sensitive detection of the pathogen in latently infected plants.
\end{abstract}

One of the most devastating Xanthomonas diseases affecting the cut flower industry worldwide is bacterial blight in aroids. Aroids include species and cultivars of Anthurium, Aglaonema, Dieffenbachia, Epipremnum, Philodendron, Spathiphyllum, and Syngonium. The disease is a persistent threat to Anthurium growers worldwide because latently infected plants, propagated by tissue-culture, harbor the pathogen for several months without exhibiting any biological symptoms $(28,29)$ and also because of its quick spread to clean fields by aerosols $(4,39)$. Tolerant varieties of Anthurium tend to act as permanent reservoirs of the pathogen, although they sustain the production of flowers in the presence of the disease $(11,12)$. Xanthomonas axonopodis pv. dieffenbachiae (37) $(=X$. campestris pv. dieffenbachiae [23]) was first described as the causal agent of the disease of Dieffenbachia maculata (Lodd.) G. Don (syn. D. picta) in 1939. Several other aroid species

Corresponding author: M. H. R. Khoodoo

E-mail: khoodoom@mx.uom.ac.mu

Accepted for publication 26 April 2004.

Publication no. D-2004-0630-01R

(C) 2004 The American Phytopathological Society were reported to be susceptible to Xanthomonas blight (17,24-26). Production losses exceeding $\$ 5$ million have been reported in Hawaii (9). In spite of the use of strict sanitation to control the disease, there has been more than a $50 \%$ loss of plants in Hawaii (11). All Araceae taxa are potential sources of infection (30).

The pathovar dieffenbachiae is known to be serologically diverse and comprises 12 known serotypes (20). A biochemical diversity was also revealed by starch hydrolysis and oxidation of 95 substrates (BIOLOG, Hayward, CA) in a study by Alvarez et al. (3). The analysis of genomic DNA using PCR-based methods has proven to be a fast, sensitive, and reliable method for determining genetic relationships among pathogenic organisms. Several methodologies are currently available for studying genetic variability among strains of the same organism/pathovar. These include various modifications of the polymerase chain reaction (PCR), such as the random amplification of polymorphic DNA (RAPD) $(40,41)$ and DNA amplification fingerprinting (8).

RAPD-PCR has the potential to detect polymorphism throughout the entire genome as compared to other techniques such as ribotyping (14). This technique can produce a spectrum of amplified products, characteristic of the template DNA due to arbitrary priming, at a relatively low annealing temperature, at multiple locations. RAPD markers have been used for strain differentiation (27), identification, and other genetic analyses for several plant $(10,13,42)$, fungal $(5,15)$, and bacterial genera $(1,14,16,22,31)$.

This work was carried out to investigate the use of the RAPD technique to generate polymorphic markers for $X$. campestris pv. dieffenbachiae and DNA probes for different groups of strains within the pathovar dieffenbachiae. The relationships among strains isolated from different hosts and from different geographical regions were also investigated.

\section{MATERIALS AND METHODS}

Bacterial strains. Table 1 indicates the origin of the strains used in this study. Because of phytosanitary measures, the DNA of foreign strains of $X$. axonopodis pv. dieffenbachiae and not live cells were obtained from collections in Hawaii and New Zealand. Three nonpathogenic Xanthomonas strains (HK56, DK02, and DK04), isolated from Mauritian aroids in a previous study (unpublished), were also included here.

DNA extraction. DNA was extracted from 50-ml overnight cultures in nutrient yeast extract glycerol broth (NYGB) by using a combination of protocols described by Ausubel et al. (6) and Lazo et al. (18). Cells were pelleted at $5,000 \mathrm{rpm}$ and washed twice in $10 \mathrm{ml}$ of STE buffer (50 $\mathrm{mM}$ Tris, $150 \mathrm{mM} \mathrm{NaCl}, 50 \mathrm{mM} \mathrm{Na}$ EDTA). After resuspension in STE and cell lysis, the lysate was treated with $\mathrm{CTAB} / \mathrm{NaCl}$ mixture and chloroform extracted as described by Ausubel et al. (6). The $\mathrm{CTAB} / \mathrm{NaCl}$ treatment and chloroform extraction were repeated until there was no precipitate between the aqueous and organic phases, and the nucleic acids were precipitated in isopropanol.

RAPD reaction. One hundred and eleven primers of $10 \mathrm{bp}$ and 60 to $80 \% \mathrm{GC}$ content (Proligo, Singapore) were screened for their ability to differentiate among isolates. Reaction parameters such as the concentration of $\mathrm{MgCl}_{2}$, primer, and DNA template were sequentially varied until optimal conditions were found to produce reproducible RAPD fingerprints. All the other primers were then tested under the same conditions. DNA concentrations tested were $2,5,10,15,20,25,30$, and 40 ng; $\mathrm{MgCl}_{2}$ concentrations tested were 1.5 , 
$2.0,2.5,3.0,3.5$, and $4.0 \mathrm{mM}$; and primer amounts were $6,8,10,12,14,16,18$, and 20 pmol. Reactions were set on ice to a final volume of $30 \mu \mathrm{l}$. Amplifications were performed in a thermal cycler (Techne Cyclogene, Cambridge, UK) programmed as follows: 1 cycle of $2 \mathrm{~min}$ at $94^{\circ} \mathrm{C}, 40$ cycles of $1 \mathrm{~min}$ at $94^{\circ} \mathrm{C}, 1 \mathrm{~min}$ at $35^{\circ} \mathrm{C}$, and $2 \mathrm{~min}$ at $72^{\circ} \mathrm{C}$, and a final extension of $10 \mathrm{~min}$ at $72^{\circ} \mathrm{C}$. The PCR products were kept at $-25^{\circ} \mathrm{C}$ until further analysis. PCR products were run on a $2.0 \%$ agarose gel and the banding profiles recorded using the Advanced American Biotechnology (AAB) system comprising a camera placed on a UV-transilluminator (302 $\mathrm{nm})$ linked to computer software allowing image capturing.

Screening and selection of primers for RAPD-PCR. Primers were first selected on the basis of the polymorphic bands common to three reference strains of $X$. axonopodis pv. dieffenbachiae (JV505, JR579, and JV589, respectively) but absent in the RAPD fingerprints of the other two isolates, $X$. campestris pv. campestris and $X$. axonopodis pv. vesicatoria.

The selected primers were then used in PCR reactions with a larger number of control bacterial DNA templates (Table 1). Primers yielding profiles common to $X$. axonopodis pv. dieffenbachiae strains and different from those of other pathovars/species of Xanthomonas were kept for further amplifications with the $22 X$. axonopodis pv. dieffenbachiae strains and three nonpathogenic Mauritius strains (Table 1).

Scoring and statistical analysis of fingerprints. Clearly visible and reproducible RAPD products were scored from photographs of ethidium bromide stained gels. The presence or absence of bands was recorded, and the scores for each primer were merged in a Microsoft Excel spreadsheet.

NTSYS-pc V1.8 (33) computer software was used for cluster analysis of the independent markers. The generated pairwise similarity matrix was used to group strains by the unweighted pair group method, arithmetic average (UPGMA; 35). A dendrogram was derived from the similarity matrix.

Reproducibility testing. All amplification reactions with selected RAPD primers were repeated once again and loaded on agarose gels for Southern blotting. The
RAPD profiles were checked after electrophoresis for their identity to the previous respective reactions. The presence of a specific band in both sets of amplifications and the reproduction of the respective signals in Southern analyses served as evidence of reproducibility.

Southern analysis. DNA fragments specific to $X$. axonopodis pv. dieffenbachiae strains were isolated from agarose gels by the use of the Rapid Gel Extraction System (Life Technologies, Rockville, MD) and used as probes in Southern hybridizations. Digoxygenin (DIG) labeling was performed by the random-primed method using the Dig-high prime kit (Boehringer Mannheim, Indianapolis, IN) for the incorporation of DIG dUTP. Fifteen microliters of RAPD products were separated on a $0.8 \%$ agarose gel. The DNA fragments were transferred to a Hybond-N nylon hybridization membrane (Amersham, Buckinghamshire, England) overnight by Southern transfer. The DNA was fixed by cross linking after exposure to UV light. Hybridizations were allowed to take place overnight at $55^{\circ} \mathrm{C}$.

Chemiluminescent detection. Chemiluminescent detection was performed on

Table 1. Origins of bacterial strains used in the study

\begin{tabular}{|c|c|c|c|}
\hline Isolate/strain & Host & Location & Source or reference \\
\hline $\begin{array}{l}\text { Xanthomonas axonopodis pv. dieffenbachiae JV502, } \\
\text { JV505, } \\
\text { JV511, } \\
\text { JV589, } \\
\text { JR579 (type strain LMG695), } \\
\text { D15-3, D108, D147 (all of serotype 1), D93 and D194 (serotype 8), } \\
\text { X1 (serotype 10), D99 (serotype 12), } \\
\text { ICMP 9564, ICMP 9565, } \\
\text { ICMP 9841, } \\
\text { ICMP 7461 (LMG8664), ICMP 4656, } \\
\text { ICMP 9569, ICMP 576, } \\
\text { ICMP 9570, } \\
\text { ICMP 9566, ICMP 9586, } \\
\text { HK56 (nonpathogenic on Anthurium), } \\
\text { DK02 (nonpathogenic on Anthurium), } \\
\text { DK04 (nonpathogenic on Anthurium) }\end{array}$ & $\begin{array}{l}\text { Anthurium } \\
\text { Anthurium } \\
\text { Anthurium } \\
\text { Anthurium } \\
\text { Anthurium } \\
\text { Anthurium } \\
\text { Anthurium } \\
\text { Anthurium } \\
\text { Anthurium } \\
\text { Anthurium } \\
\text { Dieffenbachia } \\
\text { Epipremnum } \\
\text { Philodendron } \\
\text { Dieffenbachia } \\
\text { Anthurium } \\
\text { Aglaonema }\end{array}$ & $\begin{array}{l}\text { Venezuela } \\
\text { Hawaii } \\
\text { Puerto Rico } \\
\text { Reunion } \\
\text { Brazil } \\
\text { Hawaii } \\
\text { Hawaii } \\
\text { South Florida } \\
\text { Tahiti } \\
\text { Brazil } \\
\text { Florida } \\
\text { Florida } \\
\text { Florida } \\
\text { Mauritius } \\
\text { Mauritius } \\
\text { Mauritius }\end{array}$ & $\begin{array}{l}\text { I. Soustradea } \\
\text { I. Soustrade } \\
\text { I. Soustrade } \\
\text { I. Soustrade } \\
\text { I. Soustrade } \\
\text { A. Alvarez } \\
\text { A. Alvarez } \\
\text { J. Young } \\
\text { J. Young } \\
\text { J. Young } \\
\text { J. Young } \\
\text { J. Young } \\
\text { J. Young } \\
\text { M. H. R. Khoodood } \\
\text { M. H. R. Khoodoo } \\
\text { M. H. R. Khoodoo }\end{array}$ \\
\hline $\begin{array}{l}\text { X. campestris pv. campestris } \\
\text { X. campestris pv. syngonii } \\
\text { X. axonopodis pv. begoniae } \\
\text { X. axonopodis pv. carotae } \\
\text { X. axonopodis pv. poinsetticola } \\
\text { X. axonopodis pv. phaseoli } \\
\text { X. axonopodis pv. vasculorum } \\
\text { X. axonopodis pv. vasculorum } \\
\text { X. axonopodis pv. vesicatoria } \\
\text { X. axonopodis pv. allii } \\
X . \text { axonopodis pv. malvacearum } \\
\text { X. translucens pv. translucens } \\
\text { X. vasicola } \text { pv. holcicola } \\
\text { X. albilineans } \\
\text { Pseudomonas rubrisubalbicans } \\
\text { Erwinia chrysanthemi } \\
\text { Ralstonia solanacearum }\end{array}$ & $\begin{array}{l}\text { Cabbage } \\
\text { Syngonium } \\
\text { Begonia } \\
\text { Carrot } \\
\text { Poinsettia } \\
\text { Bean } \\
\text { Sugar cane } \\
\text { Broom bamboo } \\
\text { Tomato } \\
\text { Onion } \\
\text { Cotton } \\
\text { Wheat } \\
\text { Sorghum } \\
\text { Sugar cane } \\
\text { Sugar cane } \\
\text { Potato } \\
\text { Tomato }\end{array}$ & $\begin{array}{l}\text { Mauritius } \\
\text { Mauritius } \\
\text { Mauritius } \\
\text { Mauritius } \\
\text { Mauritius } \\
\text { Mauritius } \\
\text { Mauritius } \\
\text { Mauritius } \\
\text { Mauritius } \\
\text { Mauritius } \\
\ldots \ldots \\
\ldots \\
\ldots \\
\text { Mauritius } \\
\ldots \\
\ldots \\
\text { Mauritius }\end{array}$ & $\begin{array}{l}\text { This study } \\
\text { This study } \\
\text { This study } \\
\text { This study } \\
\text { This study } \\
\text { This study } \\
\text { A. Dookun-Saumtallye } \\
\text { A. Dookun-Saumtally } \\
\text { This study } \\
\text { S. Soomary } \\
\text { Y. Jaufeerally-Fakimg } \\
\text { Y. Jaufeerally-Fakim } \\
\text { Y. Jaufeerally-Fakim } \\
\text { A. Dookun-Saumtally } \\
\text { Y. Jaufeerally-Fakim } \\
\text { Y. Jaufeerally-Fakim } \\
\text { This study }\end{array}$ \\
\hline
\end{tabular}

a I. Soustrade, CIRAD St Pierre, Reunion Island.

b A. Alvarez, University of Hawaii, Hawaii.

c J. Young, Landcare Research Ltd., Auckland, New-Zealand.

${ }^{d}$ M. H. R. Khoodoo, Biotechnology Unit, Faculty of Agriculture, University of Mauritius, Réduit, Mauritius.

e A. Dookun-Saumtally, Mauritius Sugar Industry Research Institute (MSIRI), Réduit, Mauritius.

f S. Soomary, Agricultural Research and Extension Unit (AREU), Réduit, Mauritius.

g Y. Jaufeerally-Fakim, Biotechnology Unit, Faculty of Agriculture, University of Mauritius, Réduit, Mauritius. 
membranes using $25 \mathrm{mM}$ disodium 3-(4methoxyspiro $\{1,2$-dioxetane-3,2'-(5'-chloro) tricyclo[3.3.1.1 $\left.1^{3,7}\right]$ decan $\left.\}-4 \quad y l\right)$ phenyl phosphate (CSPD) as substrate. All procedures were followed according to the manufacturer's instructions (Boerhinger Mannheim). An X-ray film (AGFA) was exposed to the membrane for $30 \mathrm{~min}$ (longer for faint signals) before development.

\section{RESULTS}

RAPD fingerprinting. The conditions for reproducible fingerprints were $25 \mathrm{ng}$ of DNA, $0.2 \mathrm{mM}$ of each dNTP, $0.5 \mu \mathrm{M}$ of primer, $2.5 \mathrm{mM} \mathrm{MgCl}$, and 1 unit of Taq polymerase (Boerhinger Mannheim). The modification of the initial cycle parameters did not result in improved fingerprints; therefore the initial parameters were used for the whole study. Eight primers (Table 2) out of 111 allowed a comparison among $X$. axonopodis pv. dieffenbachiae strains and were selected for the study of genetic diversity. RAPD reactions were performed several times over a number of months, and the results were found to be reproducible. The descriptions for four primers are illustrated below.

Amplification polymorphism among $X$. axonopodis pv. dieffenbachiae strains was obtained with the four primers P27, P49, P54, and P59. With primer P27, a band of $1.3 \mathrm{~kb}$ was amplified from 16 out of 18 Anthurium strains (Fig. 1, lanes 1, 2, 6-9, 11-19, and 23) and one Epipremnum strain (lane 5). Bands ranging in size from about 400 to $2,300 \mathrm{bp}$ were amplified. Isolates JV502, JV505, JV589, D108, D194, and D93 (lanes 11, 12, 15, 17, 19, and 20) were distinguished by a fragment of $1,500 \mathrm{bp}$ not amplified from other strains. Strains JV502, JV511, JV579, and D99 (lanes 11, 13, 14, and 21) shared a fragment of 900 bp. Two Dieffenbachia strains (ICMP 9569 and 576; lanes 4 and 10) shared four bands (approximately 550, 600, 750, and 900 bp), but strain ICMP 576 also shared a 1,400-bp fragment with Anthurium strains ICMP 9841 and DK02 (lanes 7 and 25).

Table 2. Sequences of selected random amplified polymorphic DNA (RAPD) primers for the study of diversity

\begin{tabular}{lccc}
\hline Primer & Nucleotide sequence $\left(\mathbf{5}^{\prime} \mathbf{-} \mathbf{3}^{\prime}\right)$ & Name of probe & Size $^{\mathbf{a}}(\mathbf{b p})$ \\
\hline P27 & GGCAGGCTGT & P27-1300 & 1,300 \\
P49 & GAAACGGGTG & P49-840 & 840 \\
& & P49-1000 & 1,000 \\
P54 & CAGCACCCAC & P54-800 & 800 \\
P59 & AGGTGACCGT & & $\ldots$ \\
P69 & GTCCACACGG & & 1,300 \\
P81 & GTGAGGCGTC & & $\ldots$ \\
P86 & TGGACCGGTG & & $\ldots$ \\
P102 & TGAGCGGACA & $\ldots$ \\
\hline
\end{tabular}

${ }^{\text {a }}$ Size of probe demonstrated to be specific to Xanthomonas axonopodis pv. dieffenbachiae.
The profiles obtained with primer $\mathrm{P} 49$ are shown in Figure 2. A fragment of 840 bp was amplified from 17 out of $18 \mathrm{An}$ thurium strains (Fig. 2 lanes 1, 2, 7-9, 1119, 21, 22, and 24) and the Epipremnum strain (lane 5). However, a band of $1 \mathrm{~kb}$ was amplified from four strains (lanes 3, 4, 6, and 10) that were isolated from either Dieffenbachia (ICMP 9569 and 576) or Philodendron (ICMP 9566 and 9586). Different banding patterns were produced for strains ICMP 9564, D194, D93, D99, X1, HK56, DK04, and DK02 between 500 bp and $2 \mathrm{~kb}$ (lanes 1, 19-25).

Primer P54 also related the strains with respect to their host of origin and gave rise to relatively more complex profiles than the primers described above (Fig. 3). A fragment of $800 \mathrm{bp}$ was amplified from ICMP strains 9565, 9570, 9841, 7461, and 4656 (lanes 2, 5, 7-9) and strains JV502, JV505， JV511， JR579， JV589， D15-3, D108, and D147 (lanes 11-18). Strains ICMP 9566 and 9586 (both isolated from Philodendron) had an identical profile (lanes 3 and 6). Anthurium strains ICMP 7461, 4656, and JR579 (all isolated from Brazil) showed different profiles and shared only two bands of 700 and 1,250 bp (lanes 8, 9, and 14). Strains D194 and D93 (same serotype) shared four bands of 750, 1,250, 1,400, and 1,500 bp (lanes 19 and 20).

Additional RAPD markers were generated with primer P59. A product of $790 \mathrm{bp}$ was amplified from all isolates of $X$. axonopodis pv. dieffenbachiae except those of serotype 8 (D194 and D93; Fig. 4, lanes 19 and 20). Strains D93 and D194 were distinguished by a 1,050-bp band not present in other strains. A fragment of $1 \mathrm{~kb}$

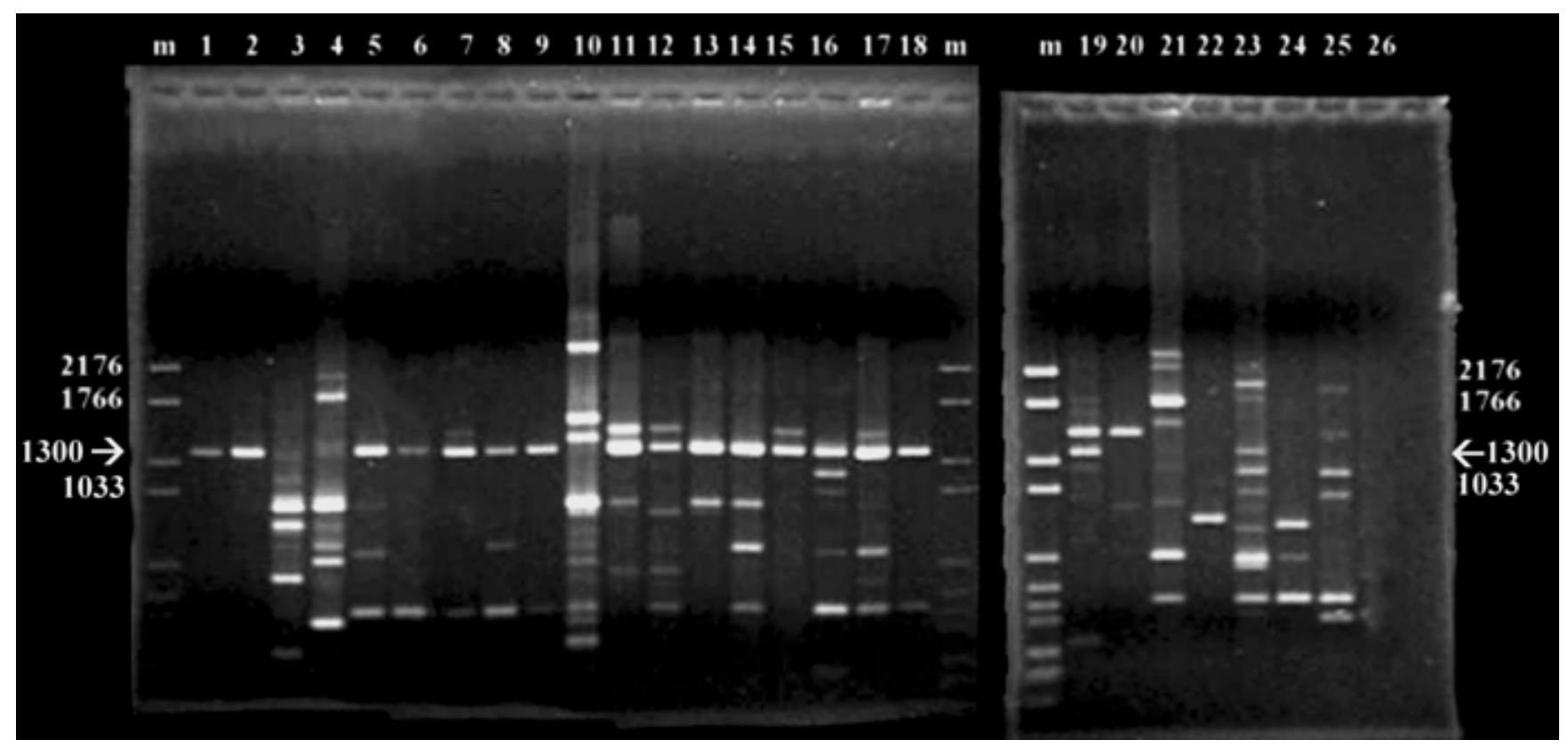

Fig. 1. Random amplified polymorphic DNA profiles obtained with primer P27. Lanes m, DNA size marker VI; lanes 1-25, Xanthomonas axonopodis pv. dieffenbachiae strains: lane 1, ICMP 9564; lane 2, ICMP 9565; lane 3, ICMP 9566; lane 4, ICMP 9569; lane 5, ICMP 9570; lane 6, ICMP 9586; lane 7, ICMP 9841; lane 8, ICMP 7461; lane 9, ICMP 4656; lane 10, ICMP 576; lane 11, JV502; lane 12, JV505; lane 13, JV511; lane 14, JR579; lane 15, JV589; lane 16, D15-3; lane 17, D108; lane 18, D147; lane 19, D194; lane 20, D93; lane 21, D99; lane 22, X1; lane 23, HK56; lane 24, DK04; lane 25, DK02. Lane 26, negative control. 
was observed in 14 strains isolated from Anthurium (lanes 2, 7-9, 11-19, and 25) and the Epipremnum strain (lane 5). However, Anthurium strains ICMP 9564, D93, D99, and X1 (lanes 1, 20-22) and strains ICMP 9566, 9569, 9586, and 576 (isolated from Philodendron and Dieffenbachia) did not produce this fragment. Different RAPD profiles could be clearly distinguished. Strains in lanes $2,5,12,16-18$ had an identical profile with four bands (790 bp, 1.0, 1.5, and $1.7 \mathrm{~kb}$ ).

Statistical analysis. Analysis of the genetic coefficient matrix derived from the scores of RAPD profiles (Fig. 5) showed that the minimum and maximum percent similarities among the isolates studied were in the range of 10 and $65 \%$, respectively. Results of cluster analysis are represented by the UPGMA dendrogram (Fig. $6)$. The isolates were clustered in four main groups (GP1, GP2, GP3, and GP4). GP1 consisted of two strains (ICMP 9564 and DK04) that were isolated from $\mathrm{An}$ thurium. Twelve out of 18 Anthurium strains and one Epipremnum strain formed GP2. Philodendron and Dieffenbachia strains were segregated into two subgroups of GP3 except for the nonpathogenic strain HK56, which was clustered in GP4. All remaining strains belonged to GP4, which also comprised a subgroup for two Hawaiian strains isolated from Anthurium (D93 and D194).

Southern hybridization analysis. The Southern analysis was useful in identifying RAPD products with sequence similarity to the one used as probe. After hybridization of PCR products in Figure 1 with probe P27-1300 (from Anthurium strain D108, amplified with primer P27), a strong signal of $1.3 \mathrm{~kb}$ was observed for 13 out of

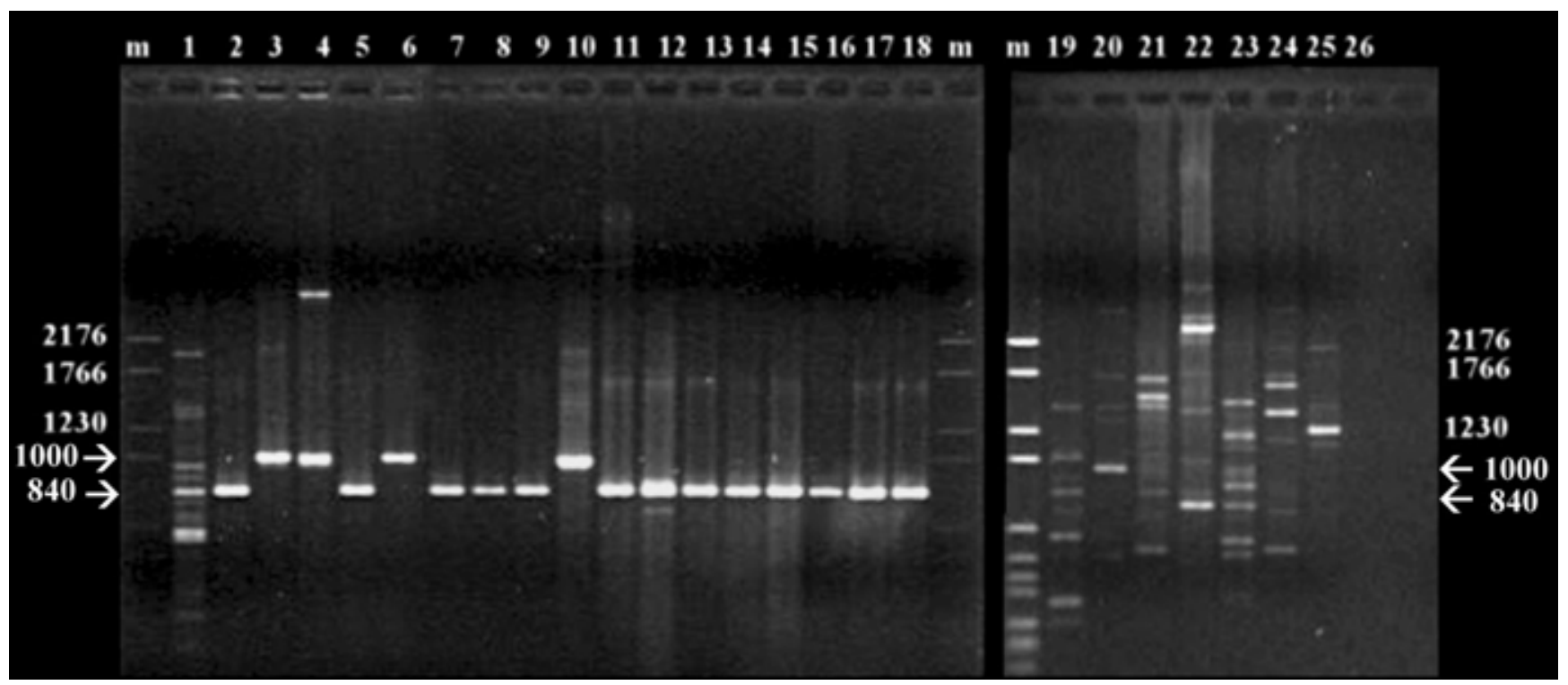

Fig. 2. Random amplified polymorphic DNA profiles obtained with primer P49. Lanes m, DNA size marker VI; lanes 1-25, Xanthomonas axonopodis pv dieffenbachiae strains: lane 1, ICMP 9564; lane 2, ICMP 9565; lane 3, ICMP 9566; lane 4, ICMP 9569; lane 5, ICMP 9570; lane 6, ICMP 9586; lane 7, ICMP 9841; lane 8, ICMP 7461; lane 9, ICMP 4656; lane 10, ICMP 576; lane 11, JV502; lane 12, JV505; lane 13, JV511; lane 14, JR579; lane 15, JV589; lane 16, D15-3; lane 17, D108; lane 18, D147; lane 19, D194; lane 20, D93; lane 21, D99; lane 22, X1; lane 23, HK56; lane 24, DK04; lane 25, DK02. Lane 26, negative control.

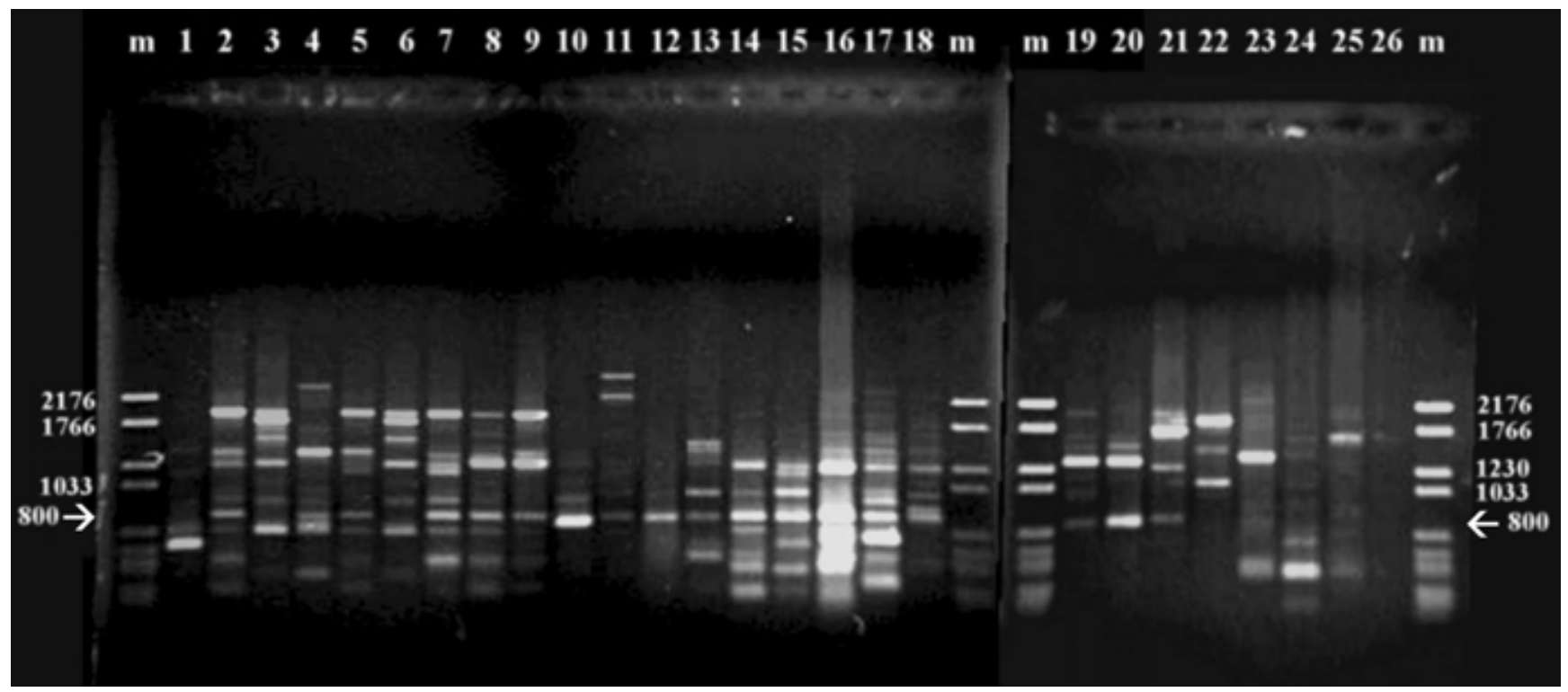

Fig. 3. Random amplified polymorphic DNA profiles obtained with primer P54. Lanes m, DNA size marker VI; lanes 1-25, Xanthomonas axonopodis pv. dieffenbachiae strains: lane 1, ICMP 9564; lane 2, ICMP 9565; lane 3, ICMP 9566; lane 4, ICMP 9569; lane 5, ICMP 9570; lane 6, ICMP 9586; lane 7, ICMP 9841; lane 8, ICMP 7461; lane 9, ICMP 4656; lane 10, ICMP 576; lane 11, JV502; lane 12, JV505; lane 13, JV511; lane 14, JR579; lane 15, JV589; lane 16, D15-3; lane 17, D108; lane 18, D147; lane 19, D194; lane 20, D93; lane 21, D99; lane 22, X1; lane 23, HK56; lane 24, DK04; lane 25, DK02. Lane 26 , negative control. 
18 Anthurium strains (ICMP 9564, 9565, 9841, 7461, 4656, JV502, JV505, JV511, JR579, JV589, D15-3, D108, and D147; Fig. 7, lanes 1, 2, 7-9, 11-18). The Epipremnum strain (ICMP 9570) and a Philodendron strain (ICMP 9586) also showed a signal of $1.3 \mathrm{~kb}$ (lanes 5 and 6). No signal was observed from control bacteria.

Figure 8 shows the results of Southern analysis of PCR products in Figure 2, using probe P49-840 (from Anthurium strain D108, amplified with primer P49). The expected signal of $840 \mathrm{bp}$ was observed for 17 Anthurium strains (ICMP 9564, 9565, 9841, 7461, 4656, JV502, JV505, JV511, JR579, JV589, D15-3, D108, D147, D194, D99, and X1; lanes 11-19, 21, and 22), one Aglaonema strain (DK04; lane 24), and the Epipremnum strain (lane 5). Dieffenbachia and Philodendron strains as well as Anthurium strains D93 and DK02 did not produce this signal. No signal was observed from control bacteria.

When PCR products in Figure 2 were hybridized to probe P49-1000 (from Dieffenbachia strain ICMP 9569, amplified with primer P49), signals of $1 \mathrm{~kb}$ were observed for strains ICMP 9566 and 9586 (from Philodendron; Fig. 9, lanes 3 and 6) and strains ICMP 9569 and 576 (from Dieffenbachia; lanes 4 and 10). The expected signal was not observed from $\mathrm{An}$ thurium strains except strains D99 and X1 (lanes 21 and 22). No signal was observed from control bacteria.

Figure 10 shows results of Southern analysis of PCR products in Figure 3 when hybridized to probe P54-800 (from Anthurium strain D108, amplified with primer P54). Anthurium strains ICMP 9565, 9841, 7461, 4656, JV502, JV505, JV511, JR579, JV589, D15-3, D108, and D147 (lanes 2, 7-9, 11-18) produced the expected signal of $800 \mathrm{bp}$. The Epipremnum strain ICMP 9570 (lane 5) also produced the signal. No signal was observed from strains isolated from other hosts and from control bacteria.

\section{DISCUSSION}

RAPD profiling has been widely used for the genetic differentiation of plant pathogens including pathovars of Xanthomonas campestris other than the pathovar dieffenbachiae (21,36). The characterization of strains of the pathovar dieffenba-

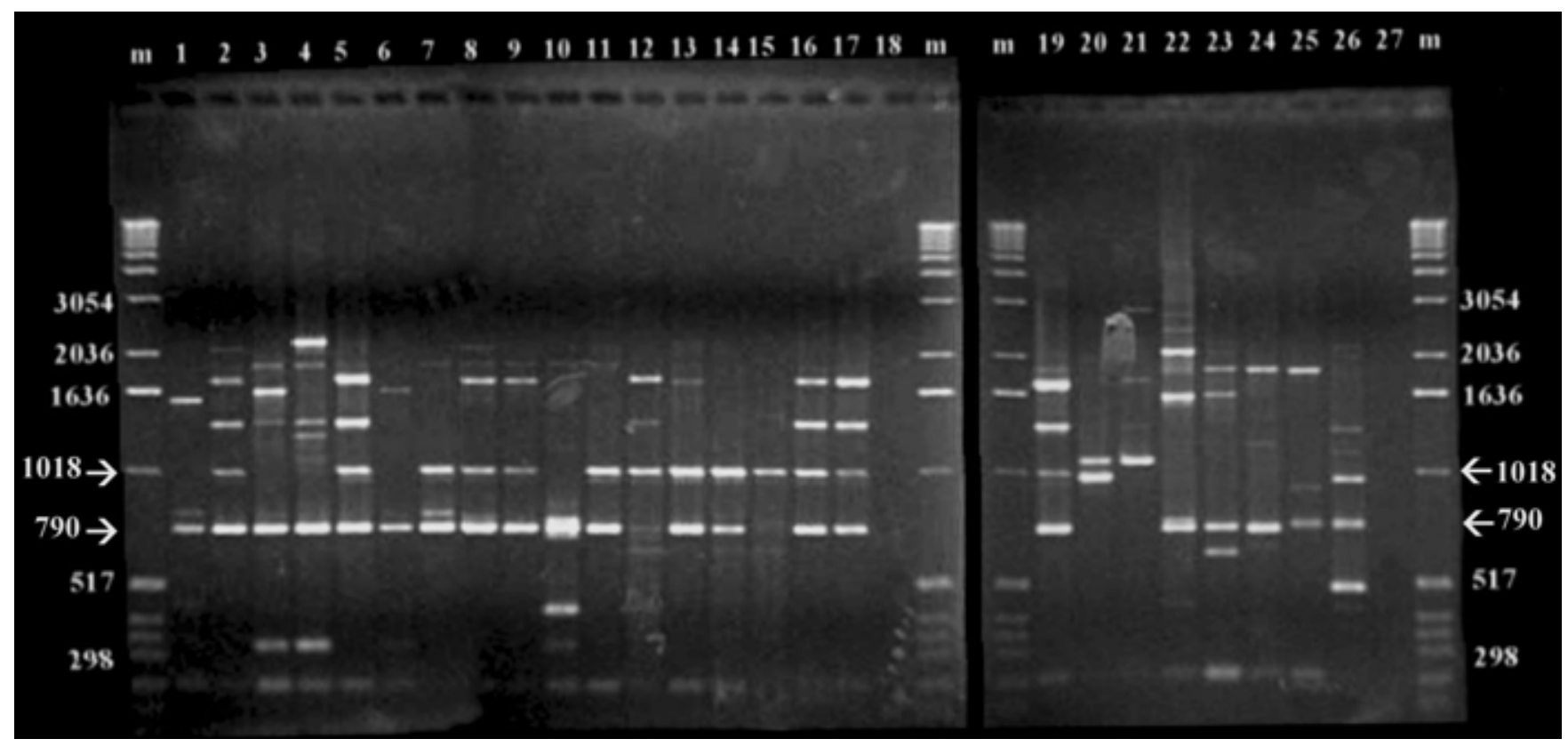

Fig. 4. Random amplified polymorphic DNA profiles obtained with primer P59. Lanes m, DNA size marker VI; lanes 1-25, Xanthomonas axonopodis pv. dieffenbachiae strains: lane 1, ICMP 9564; lane 2, ICMP 9565; lane 3, ICMP 9566; lane 4, ICMP 9569; lane 5, ICMP 9570; lane 6, ICMP 9586; lane 7, ICMP 9841; lane 8, ICMP 7461; lane 9, ICMP 4656; lane 10, ICMP 576; lane 11, JV502; lane 12, JV505; lane 13, JV511; lane 14, JR579; lane 15, JV589; lane 16, D15-3; lane 17, D108; lane 19, D147; lane 20, D194; lane 21, D93; lane 22, D99; lane 23, X1; lane 24, HK56; lane 25, DK04; lane 26, DK02. Lanes 18 and 27, negative control.

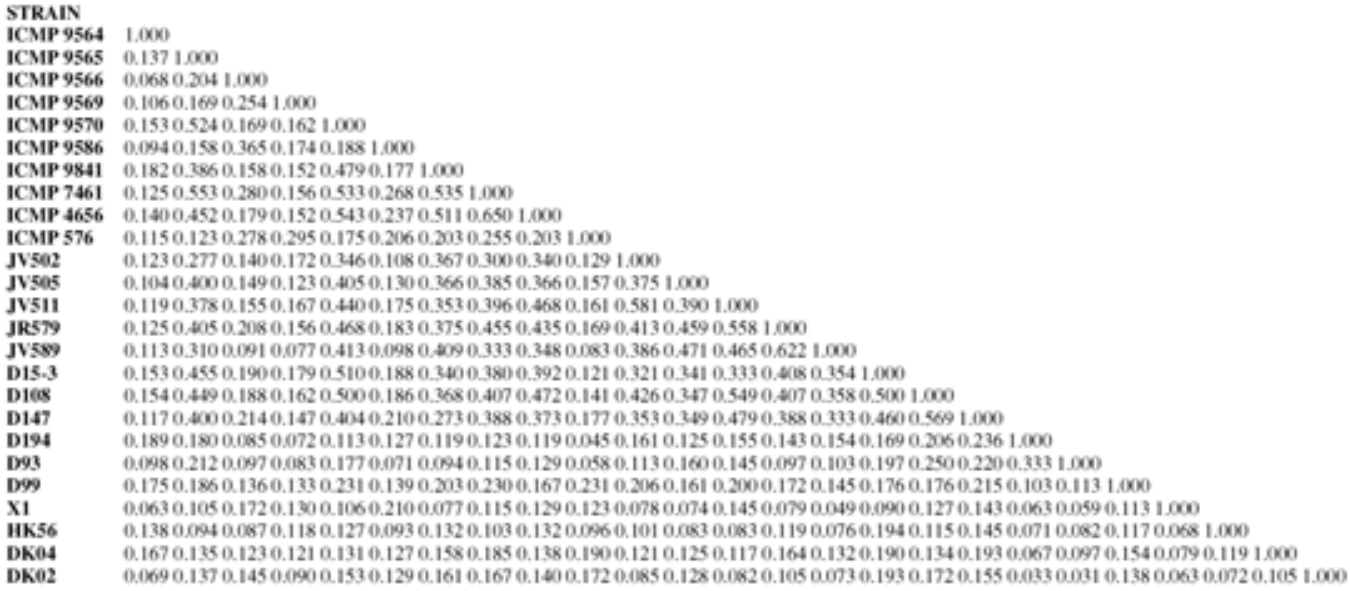

Fig. 5. Genetic similarity coefficient matrix for 25 Xanthomonas axonopodis pv. dieffenbachiae isolates based on 209 polymerase chain reaction fragment patterns obtained from eight random amplified polymorphic DNA primers. Values were calculated by Jaccard's coefficient. 
chiae has been reported using various techniques such as the physiological and fatty acid profiling (9), pathogenicity testing $(9,12)$, and biochemical analyses $(3,34)$. However, reports specifically mentioning the use of molecular techniques for analysis of the Anthurium blight pathogen mostly include serological methods (19,20,29), while those concerning DNA analyses are rare. In the absence of sequence information about the genome of the pathogen for DNA analysis, RAPD was the ideal technique to use, but because it is so sensitive to reaction conditions for the identification of genetic relatedness, an optimization of reaction parameters was required to achieve reproducibility.

Eight primers produced polymorphic banding patterns that provided information about the relatedness of $X$. axonopodis pv. dieffenbachiae strains. A few strains of known serotypes could be distinguished by their RAPD profiles. For instance, with primer P27, strains of serotype 8 (D93 and D94) shared a band of 1,550 bp (Fig. 1, lanes 19 and 20), with primer P54 four bands (Fig. 3, lanes 19 and 20), and with primer P59 a band of $1.1 \mathrm{~kb}$ (Fig. 4, lanes
19 and 20). Similarly, strains of serotype 1 (D15-3, D108, and D147) had an identical profile of four bands with primer P59 (Fig. 4, lanes 16-18), and it was observed that at least one of these bands was amplified from every strain tested. Strains D99 (serotype 12; lane 21) and X1 (serotype 10; lane 22) could be distinguished from those of serotype 1 (lanes 16-18) and serotype 8 (lanes 19 and 20) by the different profiles obtained with each of the primers used. However, since the serological information was not available for many of the strains used, one can only hypothesize a correla-

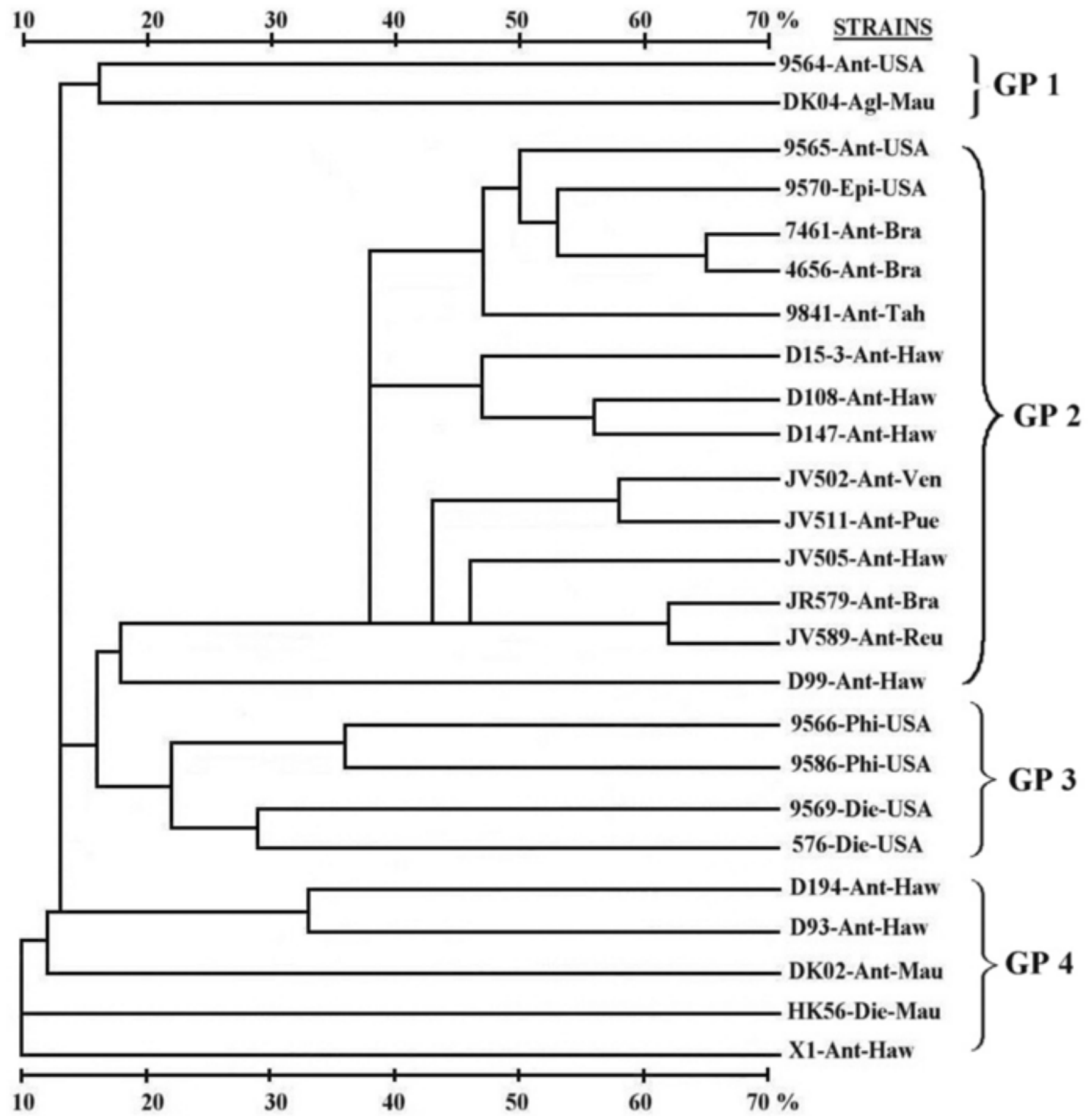

Fig. 6. Unweighted pair group method, arithmetic average dendrogram constructed from random amplified polymorphic DNA data indicating the relationship among the 25 Xanthomonas axonopodis pv. dieffenbachiae isolates of the study. The dendrogram was generated from the similarity matrix in Figure 5. Hosts are indicated as Ant $=$ Anthurium, Die $=$ Dieffenbachia, $\mathrm{Agl}=$ Aglaonema, $\mathrm{Phi}=$ Philodendron, Epi $=$ Epipremnum . Geographical origins are indicated as USA $=$ U.S. mainland, Haw $=$ Hawaii, Mau = Mauritius, Bra $=$ Brazil, Tah $=$ Tahiti, Ven $=$ Venezuela, Pue $=$ Puerto Rico. 
tion between RAPD profiling and serotyping. The UPGMA analysis confirmed that strains of serotype 1 and serotype 8 were respectively genetically similar since the reference strains for each of these serotypes were clustered together (Fig. 6).

A relationship between the RAPD profiling and the plant host was observed for some strains. For instance, primer P49 produces an 840-bp band for all reference strains isolated from Anthurium, while a 1$\mathrm{kb}$ band was amplified for reference strains that were isolated from Philodendron and Dieffenbachia (Fig. 2). These results correlate with the dendrogram (Fig. 6) where most of the reference Anthurium strains were clustered in GP2, while GP3 comprised four strains isolated from Philoden- dron and Dieffenbachia. The strain isolated from Epipremnum (ICMP 9570) was grouped with Anthurium strains in GP2 and was therefore expected to be genetically closer to these strains than to strains isolated from other aroids. No geographical correlation could be found, as X. axonopodis pv. dieffenbachiae strains isolated from the same region were often found in different groups, except for two Brazil strains (ICMP 7461 and 4656) and two Hawaii strains (D108 and D147). A significantly high percent similarity (60\%) was observed between a strain isolated in Reunion (JV589) and the type strain from Brazil (JR579), suggesting a common origin.

Southern hybridization patterns correlated with the UPGMA clustering. The probe of $1.3 \mathrm{~kb}$ isolated from the profile of an Anthurium strain amplified with primer P27 gave a strong signal for one strain in GP1 (Fig. 7, lane 1) and all strains in GP2

(Fig. 7, lanes 2, 5-9, 11-18) except strain D99 (lane 21). Strains belonging to GP3 and GP4 did not produce a signal with this probe. Similarly, the 800 -bp probe isolated from profiles amplified with primer P54 gave a signal for all strains belonging to GP2 only (Fig. 10). The probe of $840 \mathrm{bp}$ isolated from profiles amplified with primer P49 hybridized strongly to all strains clustered in GP1 (Fig. 8, lanes 1 and 24) and GP2 (Fig. 8, lanes 2, 7-9, 1118 , and 21), and two strains from GP4 (Fig. 8, lanes 19 and 22). Strains clustered in GP3 did not give a signal. The second

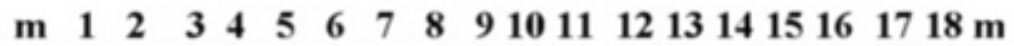
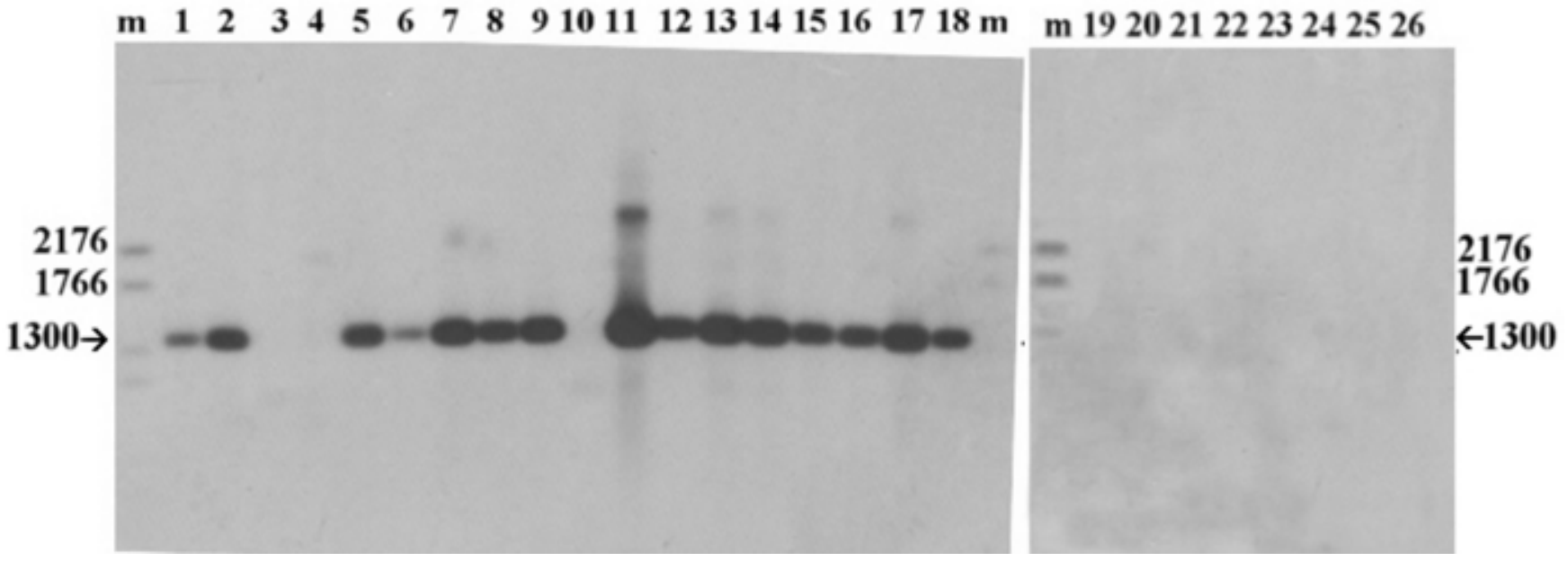

Fig. 7. Southern hybridization of polymerase chain reaction products from Figure 1 with probe P27-1300 (1.3 kb, isolated from Anthurium strain D108). Lanes m, DNA size marker VI; lanes 1-25, Xanthomonas axonopodis pv. dieffenbachiae strains: lane 1, ICMP 9564; lane 2, ICMP 9565; lane 3, ICMP 9566; lane 4, ICMP 9569; lane 5, ICMP 9570; lane 6, ICMP 9586; lane 7, ICMP 9841; lane 8, ICMP 7461; lane 9, ICMP 4656; lane 10, ICMP 576; lane 11, JV502; lane 12, JV505; lane 13, JV511; lane 14, JR579; lane 15, JV589; lane 16, D15-3; lane 17, D108; lane 18, D147; lane 19, D194; lane 20, D93; lane 21, D99; lane 22, X1; lane 23, HK56; lane 24, DK04; lane 25, DK02. Lane 26, negative control. Hybridization profiles support the clustering in Figure 6.

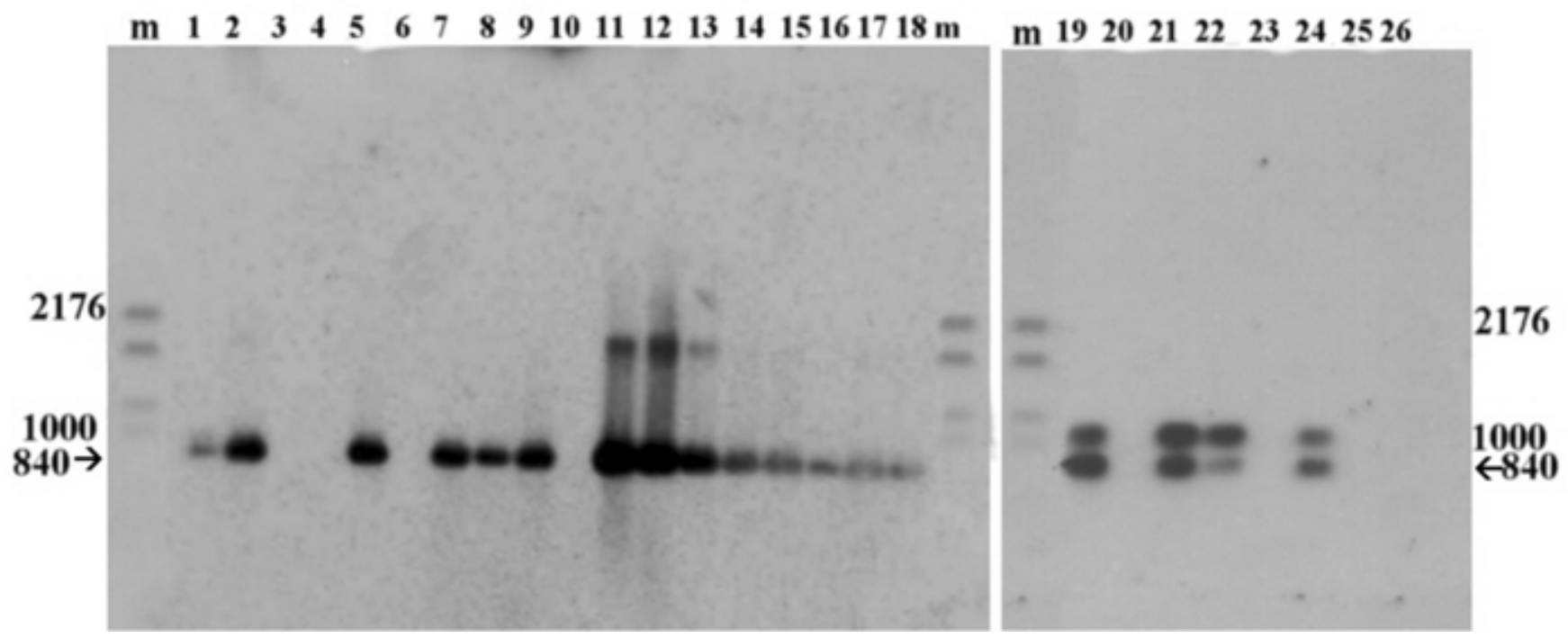

Fig. 8. Southern hybridization of polymerase chain reaction products from Figure 2 with probe P49-840 (840 bp, isolated from Anthurium strain D108), Lanes m, DNA size marker VI; lanes 1-25, Xanthomonas axonopodis pv. dieffenbachiae strains: lane 1, ICMP 9564; lane 2, ICMP 9565; lane 3, ICMP 9566; lane 4, ICMP 9569; lane 5, ICMP 9570; lane 6, ICMP 9586; lane 7, ICMP 9841; lane 8, ICMP 7461; lane 9, ICMP 4656; lane 10, ICMP 576; lane 11, JV502; lane 12, JV505; lane 13, JV511; lane 14, JR579; lane 15, JV589; lane 16, D15-3; lane 17, D108; lane 18, D147; lane 19, D194; lane 20, D93; lane 21, D99; lane 22, X1; lane 23, HK56; lane 24, DK04; lane 25, DK02. Lane 26, negative control. Hybridization profiles support the clustering in Figure 6. 
probe $(1 \mathrm{~kb})$ isolated from the profile of a Dieffenbachia strain amplified with primer P49 complemented the results of the first probe $(840 \mathrm{bp})$ by hybridizing to the respective RAPD fragment for strains clustered in GP3 (isolated from Philodendron and Dieffenbachia; Fig. 9). Apart from GP3 strains, only one strain from GP2 (Fig. 9, lane 21) and one from GP4 (Fig. 9, lane 20) produced a signal with this probe. None of the probes tested produced signals with the RAPD products amplified from control bacteria used in this study and were therefore considered to be specific to $X$. axonopodis pv. dieffenbachiae. The hybridization patterns further confirm the existence of subpopulations in the pathovar dieffenbachiae. It is therefore expected that since the pathovar is extensively diverse, more than one DNA probe or primer pair might be needed to identify all $X$. axonopodis pv. dieffenbachiae strains.

In the present study, RAPD fingerprinting confirmed the heterogeneity of the pathovar dieffenbachiae, as previously reported by Berthier et al. (7), with genetic similarities among clusters ranging from about 10 to $65 \%$. Jaccard's coefficient (35), used in the analysis, does not consider the joint absence of a marker as an indication of genetic similarity (2); therefore, the reliability of the analysis is enhanced with respect to the presence of clearly amplified RAPD markers. Although the analysis involved a small number of strains of the blight pathogen, the results obtained showed that RAPD markers are valuable tools for the study of the genetic relatedness among $X$. axonopo- dis pv. dieffenbachiae strains. However, more strains would need to be studied to confirm the correlation among RAPD profiling, serotyping, and host range. The DNA probes that were developed from RAPD fragments complemented each other in the Southern analysis to give their respective signals for the range of reference strains used. As previously reported for Xanthomonas axonopodis pv. pelargonii, RAPD markers can be used to develop specific DNA primers for the detection of the pathogen in infected plants (21). The RAPD markers that were used in this study are presently being sequenced to develop a sensitive diagnostic tool for Anthurium blight.

The current classification of xanthomonads is based on DNA homology, repetitive

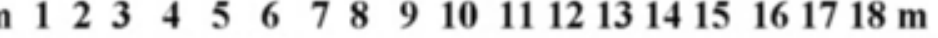

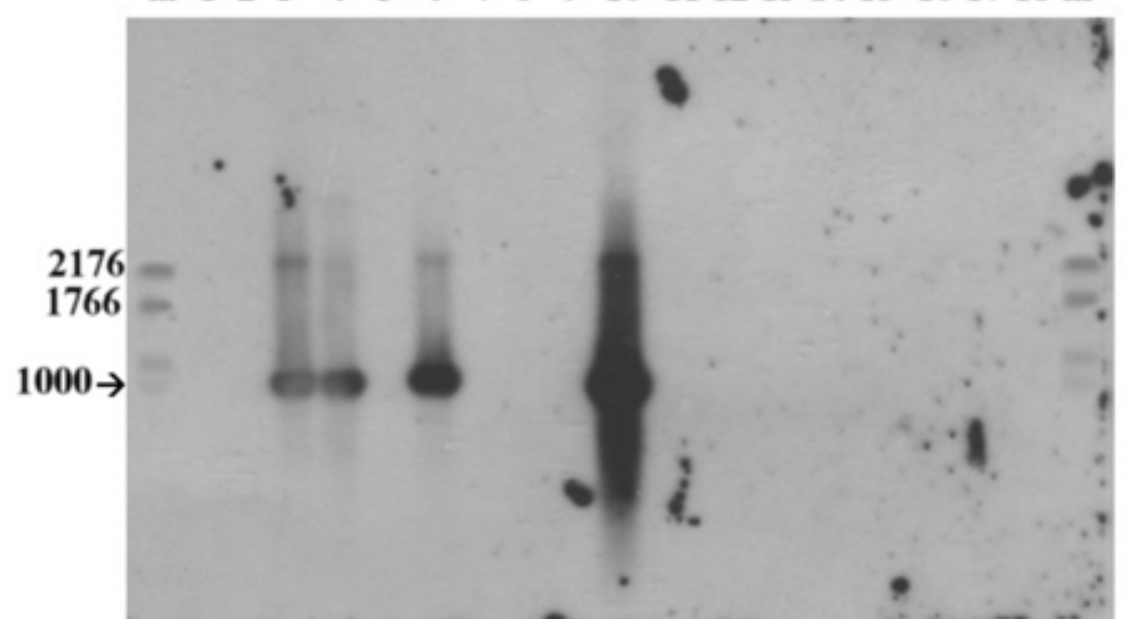

m 1920212223242526

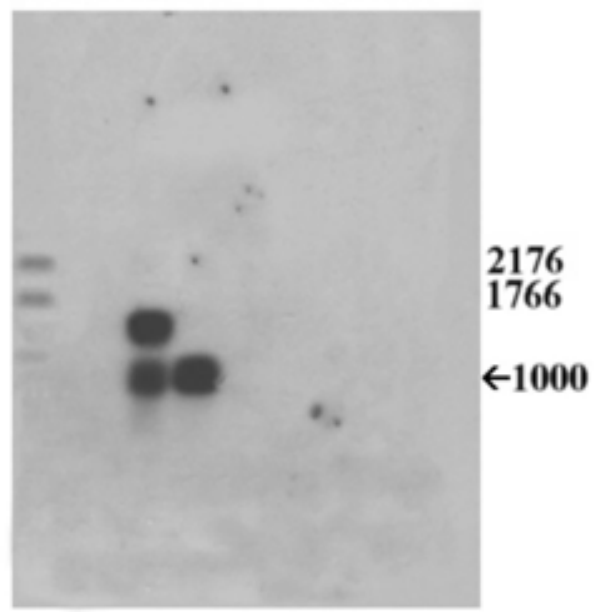

Fig. 9. Southern hybridization of polymerase chain reaction products from Figure 2 with probe P49-1000 (1 kb, isolated from the Dieffenbachia strain ICMP 9569). Lanes m, DNA size marker VI; lanes 1-25, Xanthomonas axonopodis pv. dieffenbachiae strains: lane 1, ICMP 9564; lane 2, ICMP 9565; lane 3, ICMP 9566; lane 4, ICMP 9569; lane 5, ICMP 9570; lane 6, ICMP 9586; lane 7, ICMP 9841; lane 8, ICMP 7461; lane 9, ICMP 4656; lane 10, ICMP 576; lane 11, JV502; lane 12, JV505; lane 13, JV511; lane 14, JR579; lane 15, JV589; lane 16, D15-3; lane 17, D108; lane 18, D147; lane 19, D194; lane 20, D93; lane 21, D99; lane 22, X1; lane 23, HK56; lane 24, DK04; lane 25, DK02. Lane 26, negative control. Hybridization profiles support the clustering in Figure 6.

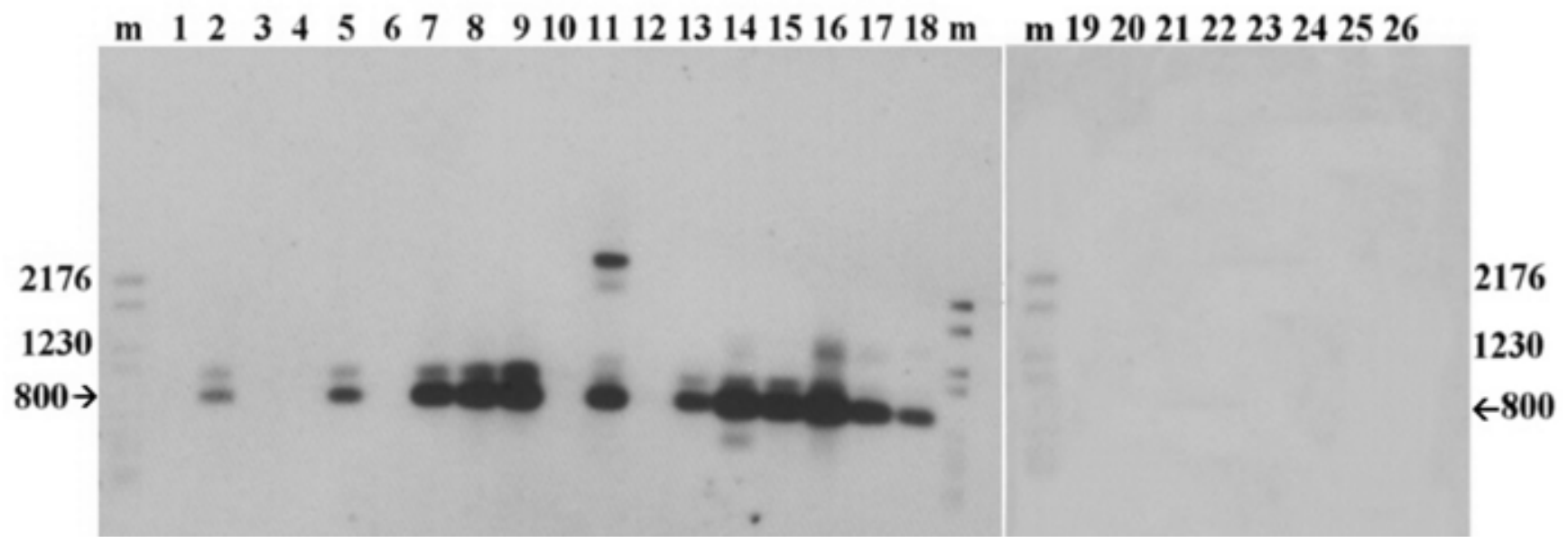

Fig. 10. Southern hybridization of polymerase chain reaction products from Figure 3 with probe P54-800 (800 bp, isolated from Anthurium strain D108). Lanes m, DNA size marker VI; lanes 1-25, Xanthomonas axonopodis pv. dieffenbachiae strains: lane 1, ICMP 9564; lane 2, ICMP 9565; lane 3, ICMP 9566; lane 4, ICMP 9569; lane 5, ICMP 9570; lane 6, ICMP 9586; lane 7, ICMP 9841; lane 8, ICMP 7461; lane 9, ICMP 4656; lane 10, ICMP 576; lane 11, JV502; lane 12, JV505; lane 13, JV511; lane 14, JR579; lane 15, JV589; lane 16, D15-3; lane 17, D108; lane 18, D147; lane 19, D194; lane 20, D93; lane 21, D99; lane 22, X1; lane 23, HK56; lane 24, DK04; lane 25, DK02. Lane 26, negative control. Hybridization profiles support the clustering in Figure 6. 
extragenic palindromic (REP)-PCR, and amplified fragment length polymorphism (AFLP) $(32,37,38)$. However, for many groups it has not yet been possible to classify pathovars using genomic information based on these fingerprints (38). The probes used in this study indicate that Xanthomonas isolates from aroids have undergone evolutionary changes, possibly as part of the speciation process. Three out of four probes that were isolated from $A n$ thurium strains did not hybridize to strains that were isolated from Philodendron and Dieffenbachia. However, the fourth probe (P49-1000, which was isolated from a Dieffenbachia strain) hybridized to Philodendron and Dieffenbachia strains as well as to two Anthurium strains. Since the probes did not hybridize to the controls and were specific to $X$. axonopodis pv. dieffenbachiae, it could be speculated that the isolates from aroids might have originated from a common ancestor. However, a larger number of strains from different aroids should be screened to confirm this observation.

\section{ACKNOWLEDGMENTS}

This work was funded by a grant from the Mauritius Research Council (MRC) and a scholarship from the University of Mauritius. We thank all the persons and institutions who have kindly provided the DNA samples of foreign $X$. axonopodis pv. dieffenbachiae strains.

\section{LITERATURE CITED}

1. Akopyanz, N., Bukanov, N. O., Westblom, T. U., Kresovich, S., and Berg, D. E. 1992. DNA diversity among clonical isolates of Helicobacter pylori detected by PCR-based RAPD fingerprinting. Nucleic Acids Res. 20:51375142.

2. Aljanabi, S. M., Loiácono, M. S., Lourenço, R. T., Borges, M., and Tigano, M. S. 1998. RAPD analysis revealing polymorphism in egg parasitoids of soybean stink bugs (Hemiptera: Pentatomidae). Ann. Soc. Entomol. Brasil 27:413420.

3. Alvarez, A., Lipp, R., Norman, D., and Benedict, A. 1991. Population diversity and distribution of Xanthomonas campestris pv. dieffenbachiae. (Abstr.) Phytopathology 81:1172.

4. Alvarez, A. M., Venette, J., and Norman, D. 1994. Relationship of aerosols to Anthurium blight. Pages 20-26 in: Proc. Hawaii Anthurium Industry Conf., 5th. K. M. Debate and C. H. M. Tome, eds. HITAHR Journal series 02.02.94. University of Hawaii, Honolulu.

5. Assigbetse, K. B., Fernandez, D., Dubois, M. P., and Geiger, J. P. 1994. Differentiation of Fusarium oxysporum f. sp. vasinfectum races on cotton by random amplification of polymorphic DNA (RAPD) analysis. Mol. Plant Pathol. 84:622-626.

6. Ausubel, F. H., Brent, R., Kingston, R. E., Moore, D. D., Seidman, J. G., Smith, J. A., and Struth, K. 1994. Page 241 in: Current Protocols in Molecular Biology. John Wiley \& Sons, Chichester, Canada.

7. Berthier, Y., Thierry, D., Lemattre, M., and Guesdon, J.-L. 1994. Isolation of an insertion sequence (IS1051) from Xanthomonas campestris pv. dieffenbachiae with potential use for strain identification and characterization. Appl. Environ. Microbiol. 60:377-384.

8. Caetano-Anollés, G., Bassam, B. J., and Gresshoff, P. M. 1991. DNA amplification fingerprinting using very short arbitrary oligonucleotide primers. Biotechnology 9:553-556.

9. Chase, A. R., Stall, R. E., Hodge, N. C., and Jones, J. B. 1992. Characterization of Xanthomonas campestris strains from aroids using physiological, pathological, and fatty acid analyses. Phytopathology 82:754-759.

10. Devey, M. E., Bell, J. C., Smith, D. N., Neale, D. B., and Moran, G. F. 1996. A genetic linkage map for Pinus radiata based on RFLP, RAPD, and microsatellite markers. Theor. Appl. Genet. 92:673-679.

11. Fukui, H., Alvarez, A. M., and Fukui, R. 1998. Differential susceptibility of anthurium cultivars to bacterial blight in foliar and systemic infection phases. Plant Dis. 82:800-806.

12. Fukui, R., Fukui, H., and Alvarez, A. 1998. Bacterial blight of Anthurium suppressed by a mixture of four bacteria. In: Tropical and SubTropical Agriculture, Research Notes. Summer 98.

13. Haley, S. D., Miklas, P. N., Staveley, J. R., Byrum, J., and Kelly, J. D. 1993. Identification of RAPD markers linked to a major rust resistance gene block in common bean. Theor. Appl. Genet. 86:505-512.

14. Hilton, A. C., and Penn, C. W. 1998. Comparison of ribotyping and arbitrarily-primed PCR for molecular typing of Salmonella enterica and relationships between strains on the basis of these molecular markers. J. Appl. Microbiol. 85:933-940.

15. Kageyama, K., Uchino, H., and Hyakumachi, M. 1998. Characterization of the hyphal swelling group of Pythium: DNA polymorphisms and cultural and morphological characteristics. Plant Dis. $82: 218-222$

16. Khoodoo, M. H. R., Issack, M. I., and Jaufeerally-Fakim, Y. 2002. Serotyping and RAPD profiles of Salmonella enterica isolates from Mauritius. Lett. Appl. Microbiol. 35:146-152.

17. Knauss, J. F. 1972. Resistance of Xanthomonas dieffenbachiae isolated to streptomycin. Plant Dis. Rep. 56:394-397.

18. Lazo, G. R., Roffey, R., and Gabriel, D. W. 1987. Pathovars of Xanthomonas campestris are distinguishable by restriction fragment length polymorphism. J. Syst. Bacteriol. 37:214-221.

19. Lemattre, M., Narcy, J. P., Berthier, Y., Philippot, P., Jacquet, C., and Clauzel, J. M. 1992. Development of serological tools for the detection of Xanthomonas species. Plant Pathogenic Bacteria No. 66:287-291.

20. Lipp, R. L., Alvarez, A. M., Benedict, A. A., and Berestecky, J. 1992. Use of monoclonal antibodies and pathogenicity tests to characterize strains of Xanthomonas campestris pv. dieffenbachiae from aroids. Phytopathology 82:677-682.

21. Manulis, S., Valinsky, L., Lichter, A., and Gabriel, D. W. 1994. Sensitive and specific detection of Xanthomonas campestris pv. pelargonii with DNA primers and probes identified by random amplified polymorphic DNA analysis. Appl. Environ. Microbiol. 60:4094-4099.

22. Mazurier, S., Van de Giessen, A., Heuvelman, K., and Wernars, K. 1992. RAPD analysis of Campylobacter isolates: DNA fingerprinting without the need to purify DNA. Lett. Appl. Microbiol. 14:260-262.

23. McCulloch, L., and Pirone, P. P. 1939. Bacterial leaf spot of Dieffenbachia. Phytopathology 29:956-962.
24. McFadden, L. A. 1962. Two bacterial pathogens affecting leaves of Aglaonema roebelinii. (Abstr.) Phytopathology 52:20.

25. McFadden, L. A. 1963. Leaf spot of Aglaonema roebelinii (Schmismatoglottis) Univ. Fla. Agric. Ext. Serv. Orna. Hortic. Rep. $2: 1$.

26. McFadden, L. A. 1967. A Xanthomonas infection of Philodendron oxycardium leaves. (Abstr.) Phytopathology 57:343.

27. Mesquita, A. G. G., Paula, T. J., Jr., Moreira M. A., and de Barros, E. G. 1998. Identification of races of Colletotrichum lindemuthianum with the aid of PCR-based molecular markers. Plant Dis. 82:1084-1087.

28. Norman, D. J., and Alvarez, A. M. 1994. Latent infections of in vitro Anthurium caused by Xanthomonas axonopodis pv. dieffenbachiae. Plant Cell, Tissue Organ Culture 39:55-61.

29. Norman, D. J., and Alvarez, A. M. 1994. Rapid detection of Xanthomonas campestris pv. dief fenbachiae in anthurium plants with a miniplate-enrichment/ELISA system. Plant Dis. 78:954-958.

30. Norman, D. J., Henry, R. J., and Yuen, J. M. F. 1999. Resistance levels of pot Anthurium cultivars to Xanthomonas campestris pv. dieffenbachiae. HortScience 34:721-722.

31. Parent, J.-G., Lacroix, M., Pagé, D., Vézina, L., and Végiard, S. 1996. Identification of Erwinia carotovora from soft rot diseased plants by random amplified polymorphic DNA (RAPD) analysis. Plant Dis. 80:494-499.

32. Rademaker, J. L. W., Hoste, B., Louws, F. J., Kersters, K., Swings, J., Vauterin, L., Vauterin, P., and de Bruijn, F. J. 2000. Comparison of AFLP and rep-PCR genomic fingerprinting with DNA-DNA homology studies: Xanthomonas as a model system. Int. J. Syst. Evol. Microbiol. 50:665-677.

33. Rohlf, F. J. 1993. NTSYS-pc v. 1.8., Numerical Taxonomy and Multivariate Analysis System. Applied Biostatistics Inc., Setauket, NY. p. 191.

34. Rott, P., and Prior, P. 1987. Bacterial decay of Anthurium caused by Xanthomonas campestris pv. dieffenbachiae in the French West Indies. Agron. Trop. 42-1:61-68.

35. Sneath, P. A., and Sokal, R. R. 1973. Numerical Taxonomy. Freeman, San Francisco. p 573.

36. Sulzinski, M., Moorman, G., Schilagnhaufer, B., and Romaine, C. P. 1995. Fingerprinting of Xanthomonas campestris pv. perlargonii and related pathovars using random-primed PCR. J. Phytopathol. 143:429-433.

37. Vauterin, L., Hoste, B., Kersters, K., and Swings, J. 1995. Reclassification of Xanthomonas. Int. J. Syst. Bacteriol. 45:472-489.

38. Vauterin, L., Rademaker, J., and Swings, J. 2000. Synopsis on the taxonomy of the genus Xanthomonas. Phytopathology 90:677-682.

39. Venette, J., Alvarez, A. M., and Norman, D. 1992. Serological markers for monitoring Xanthomonas campestris pv. dieffenbachiae in aerosols. (Abstr.) Phytopathology 82:1178.

40. Welsh, J., and McClelland, M. 1990. Fingerprinting genomes using PCR with arbitrary primers. Nucleic Acids Res. 18:7213-7219.

41. Williams, J. G. K., Kubellick, A. R., Livak, K. J., Rafalski, J. A., and Tingey, S. V. 1990. DNA polymorphisms amplified by arbitrary primers are useful as genetic markers. Nucleic Acids Res. 18:6531-6535.

42. Yi, H.-Y., Rufty, R. C., Wernsman, E. A., and Conkling, M. C. 1998. Mapping the root-knot nematode resistance gene $(R k)$ in tobacco with RAPD markers. Plant Dis. 82:1319-1322. 